\title{
Phytopathology
}

\section{Signaling Mechanisms Underlying Resistance Responses: What Have We Learned, and How Is It Being Applied?}

\author{
Aardra Kachroo, ${ }^{\dagger}$ Paul Vincelli, and Pradeep Kachroo
}

Department of Plant Pathology, University of Kentucky, Lexington 40546.

Accepted for publication 8 June 2017.

\begin{abstract}
Plants have evolved highly specific mechanisms to resist pathogens including preformed barriers and the induction of elaborate signaling pathways. Induced signaling requires recognition of the pathogen either via conserved pathogen-derived factors or specific pathogen-encoded proteins called effectors. Recognition of these factors by host encoded receptor proteins can result in the elicitation of different tiers of resistance at the site of pathogen infection. In addition, plants induce a type of systemic immunity which is effective at the whole plant level and protects against a broad spectrum of pathogens. Advances in our understanding of pathogen-recognition mechanisms, identification of the underlying molecular components, and their significant conservation across diverse plant species has enabled the development of novel strategies to combat plant diseases. This review discusses key advances in plant defense signaling that have been adapted or have the potential to be adapted for plant protection against microbial diseases.
\end{abstract}

From mention of plant geminivirus infection in an ancient Japanese poem (Saunders et al. 2003), consumption of fungalinfected plant parts as food delicacy (Huitlacoche), to their devastating impacts on agriculture (Koeppel 2008; Singh et al. 2011; Yoshida et al. 2013), plant diseases have touched many aspects of human life. Plant diseases continue to pose a problem for crop production and the environment despite the use of cultural practices, chemicals, and resistant varieties. Combating a constant barrage of microbial pathogens is particularly an issue for plants due to their sessile nature and lack of a circulatory system. As a result, plants have evolved unique and effective modes to combat disease causing microbes by deploying sophisticated signaling mechanisms. Induced plant defense signaling results in the activation of antimicrobial compound production, cell wall reinforcement via the synthesis of lignin and callose, and the specific induction of elaborate defense signaling pathways. The various modes of induced defense provide species level resistance to nonhost pathogens, race-specific and basal resistance to virulent pathogens, and broad-spectrum systemic resistance (Fig. 1). Here, we discuss key advances in local and systemic plant defense signaling that have been/can be utilized to provide immunity against virulent microbial pathogens.

${ }^{\dagger}$ Corresponding author: A. Kachroo; E-mail: apkach2@uky.edu

(c) 2017 The American Phytopathological Society

\section{INDUCED IMMUNITY IN RESPONSE TO PATHOGEN- DERIVED ELICITORS/EFFECTORS}

The first step in active plant defense involves the recognition of pathogen-derived factors, which is achieved via a two-tiered system involving extracellular and intracellular receptors. The first tier, which provides a low degree of general resistance, involves cell surface receptors termed pattern recognition receptors (PRR). PRRs recognize a diverse set of conserved microbial components designated pathogen/microbe-associated molecular patterns (P/MAMPs). Examples include bacterial flagellin and elongation factor Tu, chitin in fungal cell walls, and beta-glucans from oomycetes. Recognition of PAMPs by PRRs results in accumulation of reactive oxygen species (ROS) and calcium bursts. This is also accompanied by the activation of protein kinase cascades and substantial transcriptional reprogramming (Bigeard et al. 2015; Monaghan and Zipfel 2012; Schwessinger and Ronald 2012; Zipfel 2009). Eventually, these enable restriction of pathogen colonization. This type of immunity is termed PAMP-triggered immunity (PTI) or basal resistance. Because PRRs recognize conserved microbial molecules, expressing them in heterologous hosts can be effective in combating a variety of related pathogens. For instance, expression of heterologous PRRs has been shown to confer bacterial resistance in banana, grapefruit, tomato, rice, and wheat (Lacombe et al. 2010; Schoonbeek et al. 2015, Schwessinger et al. 2015; Shi et al. 2016; Tripathi et al. 2014). Similarly, expression of a tomato PRR conferred fungal resistance in Arabidopsis (Fradin et al. 2011).

The second tier of resistance, which is species-specific in nature, is much more robust and effective in restricting pathogen 
proliferation. This type of resistance is triggered when specialized resistance $(\mathrm{R})$ proteins in the plant recognize specific effector (Avr) proteins from the pathogen, and is termed R-mediated or effectortriggered (ETI) immunity (Flor 1971). An early hallmark of ETI is the induction of a hypersensitive response (HR) at the site of pathogen entry (Holliday et al. 1981). However, HR may not always be observed nor is it required for the onset of ETI (Jones and Dangl 2006). HR, a form of programmed cell death thought to help confine the pathogen to the dead cells, is generally absent in PTI.

\section{RESISTANCE PROTEINS}

$R$ genes mediating defense against bacteria, fungi, viruses, oomycetes, nematodes, and insects have been identified from a variety of plants (reviewed in Césari et al. 2014; Kachroo and Kachroo 2007; Martin et al. 2003; Qi et al. 2013). Importantly, resistance signaling downstream of $\mathrm{R}$ protein activation is conserved across diverse plants making it possible to deploy $R$ genes from heterologous sources in crop protection. For example, transfer of a pair of $R$ genes from Arabidopsis to other Brassicaceae or Solanaceae members can confer resistance to bacterial and fungal pathogens, including the cucumber pathogen Colletotrichum orbiculare (Narusaka et al. 2013). Likewise, the barley $R$ gene MLA1 is fully functional in conferring resistance to powdery mildew fungi in Arabidopsis (Maekawa et al. 2012). Thus, $R$ genes have been used for developing disease-resistant crops either via conventional breeding within sexually compatible gene pools or via genetically engineering genes from heterologous sources (Chisholm et al. 2006; Jones and Dangl 2006; Wally and Punja 2010). This approach has been especially relevant for pathosystems where major $R$ loci are limited or unavailable within the crop germplasm (Kawashima et al. 2016). An example of this was the successful engineering of resistance to the bacterial spot pathogen in tomato, a very destructive disease in warm, humid production areas. Robust levels of disease control were obtained in tomato plants under field conditions using a single $R$ gene (Bs2) from pepper (Horvath et al. 2012; Tai et al. 1999). Other examples include, bacterial streak resistance in rice plants expressing the maize $R x o 1$ gene, anthracnose resistance in alfalfa via expression of Medicago truncatula RCT1, late blight resistance in cultivated potato derived from Rpi-blb2 of a wild potato relative, Asian soybean rust resistance in soybean plants expressing $C c R p p l$ from pigeonpea, rice blast resistance in rice using $R$ genes from multiple grass species, etc. (Kawashima et al. 2016; van der Vossen et al. 2005; Yang et al. 2008, 2013; Zhang et al. 2015). Pathogen-specificity and thereby efficacy against limited pathogen strains has been one drawback of deploying $R$ genes, although pyramiding multiple $R$ genes in the same background can provide resistance against multiple isolates of the same pathogen (Zhou et al. 2009). Pyramiding $R$ genes via conventional breeding has also been used to increase the durability of field resistance (Vincelli 2016).

Interestingly, in some cases pathogen resistance requires complementary pairs of $R$ genes. For instance, two $R$ genes (RPP2A and RPP2B) are required for Arabidopsis resistance against Hyaloperonospora arabidopsidis (Sinapidou et al. 2004). Similarly, pairs of $R$ genes confer resistance to Puccinia graminis in wheat and barley, and against Magnaporthe grisea in rice (Ashikawa et al. 2008; Brotman et al. 2012; Cesari et al. 2013; Lee et al. 2009; Loutre et al. 2009; Narusaka et al. 2009; Okuyama et al. 2011; Sinapidou et al. 2004; Wang et al. 2013; Yuan et al. 2011). In some cases, the same set of paired $R$ genes provide resistance to multiple diverse pathogens. For instance, the $R$ genes Prv and Fom- 1 mediate resistance to Fusarium oxysporum and Papaya ringspot virus (PRSV) in
FIGURE 1

Types of local and systemic induced defense responses. Recognition of pathogen/microbe associated molecular patterns (PAMP) by plant pattern recognition receptors (PRR) induces signaling involving the accumulation of reactive oxygen species (ROS), induction of calcium $\left(\mathrm{Ca}^{+2}\right)$ bursts and mitogen associated protein kinase (MAPK) cascades, resulting in nuclear gene induction and eventually basal resistance in the infected tissue. This

type of immunity is termed PAMP triggered immunity or PTI (blue arrows and boxes). Pathogen derived effectors can interfere with PTI (gray box). Plant resistance protein $(R)$ mediated recognition of pathogen effector induces species-specific resistance in the infected tissue often via the phytohormone salicylic acid (SA). This type of immunity is termed effector-triggered

immunity (ETI, green arrows and boxes). Induction of ETI can also trigger the accumulation of ROS, which help generate azelaic acid (AzA) via 18 carbon (C18) fatty acids (FA). AzA induces the accumulation of glycerol-3-phosphate (G3P). G3P-derived signaling together with SA-derived signaling can induce systemic broad-spectrum and transgenerational resistance.
PAMP recognition by PRR

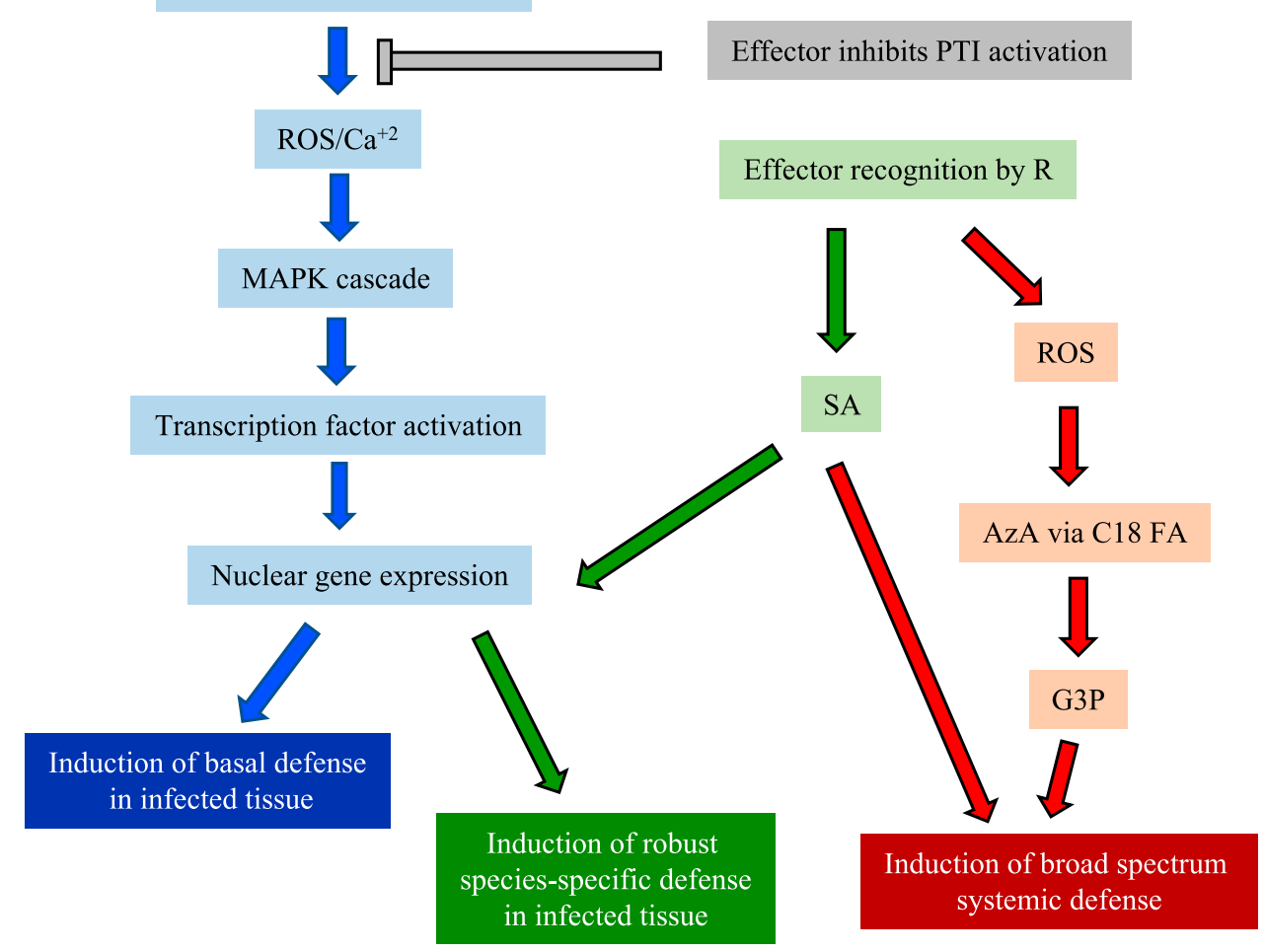


melon (Brotman et al. 2012). In Arabidopsis, RPS4 and RRS1 are required for resistance to Ralstonia solanacearum, Colletotrichum higginsianum, and the avrRps4 expressing strain of Pseudomonas syringae (Gassmann et al. 1999; Narusaka et al. 2009). Notably, in each of these cases the paired $R$ genes are tightly linked, likely ensuring their cosegregation into progeny.

Based upon their structural characteristics and motifs, R proteins can be grouped into six classes (Kachroo and Kachroo 2007; Martin et al. 2003), with most belonging to the nucleotide-binding (NB) leucine-rich repeat (LRR) family of proteins (NLR) (Fig. 2). The NLR proteins contain LRR domains at the C-terminal and a central NB-ARC (domain shared by Apaf-1, Resistance, and CED-4 proteins) domain. The NB-ARC domain is thought to function as a molecular switch, which determines the dormant and active stages of the $\mathrm{R}$ protein, and this in turn is dependent on the binding of ADP or ATP, respectively, to this domain (Maekawa et al. 2011; Tameling et al. 2002; Tameling et al. 2006; Williams et al. 2011). NLR proteins are further subclassified based on the presence of the coiled coil (CC)- or toll-interleukin 1 receptor (TIR)-domains at their N-terminal. Homodimerization has been reported for several NLR proteins, including those that regulate resistance to bacteria, fungi, and viruses, and in at least two cases homodimerization of the respective $\mathrm{CC}$ or TIR domains is crucial for downstream signaling. Dimerization between paired NLRs can also be mediated via these domains, such as the rice RGA4/RGA5 pair which interact via their CC domains, and the Arabidopsis RPS4/ RRS1 pair which interact via their TIR domains (Césari et al. 2014; Williams et al. 2014). R proteins also undergo intramolecular interactions, which are thought to be important for maintaining the protein in a dormant state. For example, in the NLR Rx (resistance to Potato virus $X$ ), interactions have been detected between the LRR and CC-NB domains as well as the CC and NB-LRR domains (Moffett et al. 2002). The viral effector is known to disrupt these intramolecular interactions suggesting a role for these disruptions in $\mathrm{Rx}$ activation. In fact, coexpression of the LRR domain with the CCNB domain or full length Rx induces HR.

\section{R PROTEIN ACTIVATION}

$\mathrm{R}$ proteins are activated upon direct or indirect association with the cognate pathogen effector(s). Direct interactions can be mediated by the CC, NB-ARC, or LRR domains of R proteins. For example, the R proteins L and RPP1, interact with their cognate effectors AvrL567 and ATR1, respectively, via their LRR domains (Dodds et al. 2006; Krasileva et al. 2010; Ravensdale et al. 2012), whereas the rice NLR Pik interacts with Avr-Pik from $M$. grisea via its CC domain (Kanzaki et al. 2012). Interestingly, in case of paired NLRs only one of the NLRs directly interacts with the cognate effector. The effectorinteracting NLR represses its paired NLR, which functions as an activator of cell death and resistance. Effector binding relieves the repression to activate resistance signaling (Cesari et al. 2013; Kanzaki et al. 2012; Williams et al. 2014).

Although some $\mathrm{R}$ proteins directly interact with their cognate effectors, most others utilize indirect modes of pathogen recognition by "guarding" other plant proteins, which interact with and/or are modified by pathogen effectors (Innes 2004; Jones and Dangl 2006; Van der Biezen and Jones 1998,). A classic example is the activation of R-mediated resistance to the avrRpt 2 strain of $P$. syringae in response to protease cleavage of the RIN4 (RPM1 interacting 4) protein by the bacterial effector (Axtell and Staskawicz 2003;

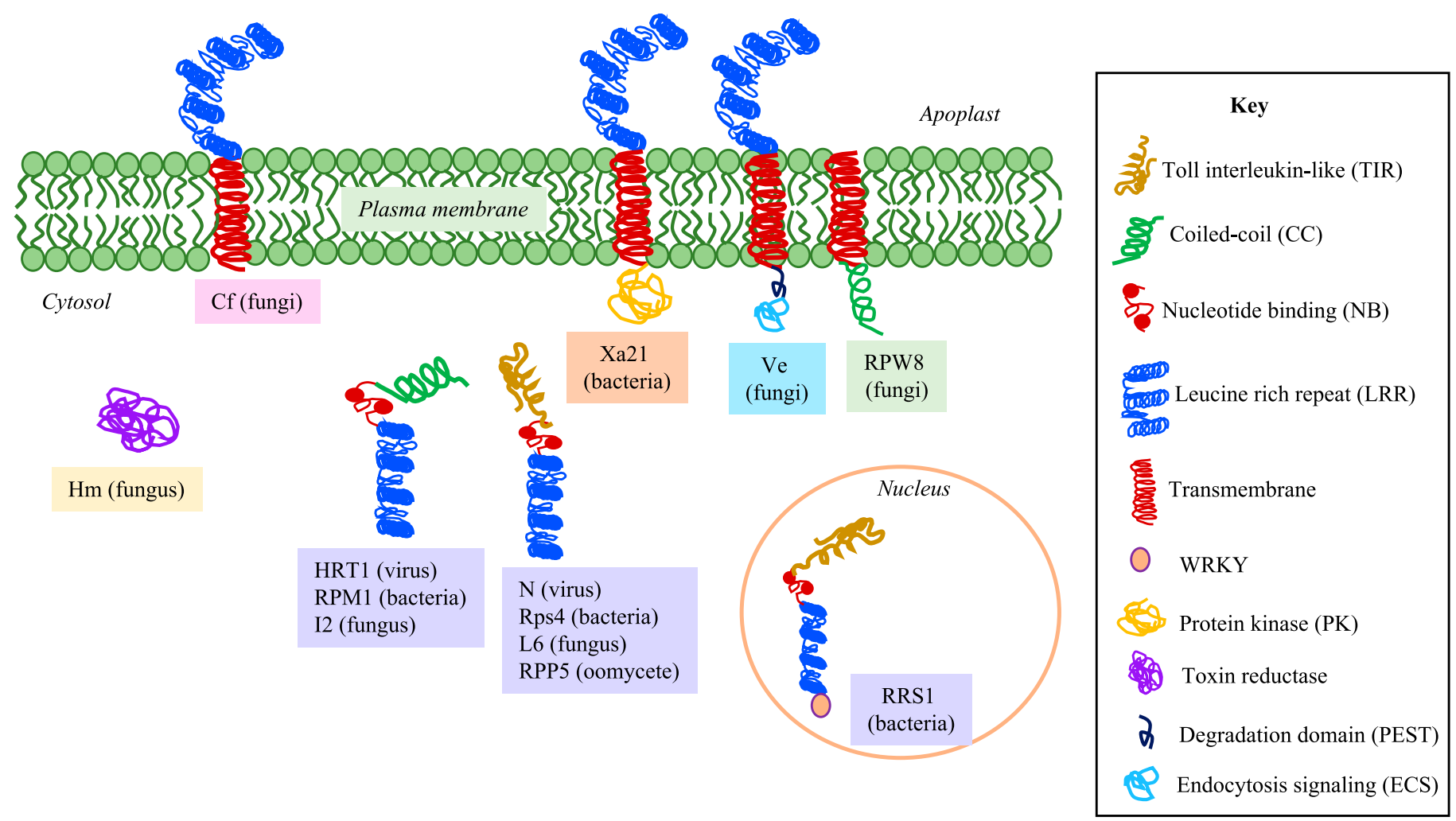

FIGURE 2

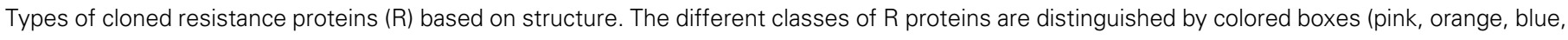

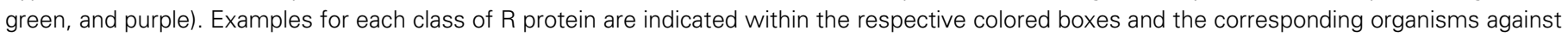

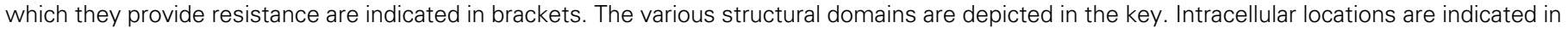

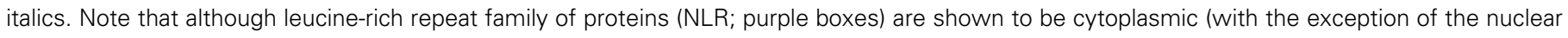

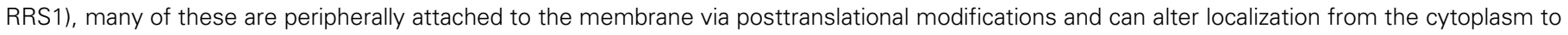
the nucleus during resistance signaling. 
Mackey et al. 2003). RIN4 can undergo a different posttranslational modification (phosphorylation) in the presence of other bacterial effectors to induce resistance from the cognate $\mathrm{R}$ protein in diverse plants (Kim et al. 2005; Luo et al. 2009; Mackey et al. 2002; Selote and Kachroo 2010; Selote al. 2013,). Similarly, cleavage of the protein kinase PBS1 (AvrPphB susceptible 1) can activate bacterial resistance derived from another $\mathrm{R}$ protein in Arabidopsis (Shao et al. 2003). Notably, some pathogen effectors target multiple host proteins. For example, the Cladosporium fulvum effector Avr2 inhibits the activities of two apoplastic papain-like cysteine proteases (PIP1 and RCR3) in tomato (Shabab et al. 2008). Inhibition of RCR3 is associated with activation of resistance derived from the $\mathrm{R}$ protein Cf2 in tomato (Rooney et al. 2005). Similarly, the P. syringae effector AvrPto inhibits the kinase domains of multiple PRRs. In plants containing the Pto (protein kinase)-Pfr (R protein) combination, inhibition of Pto activity induces ETI via Pfr (Zipfel and Rathjen 2008). Such examples led to the suggestion that related host proteins interacting with the same pathogen effector may function as "decoys" by contributing to $\mathrm{R}$ protein activation, but not serving as pathogen virulence enhancers (van der Hoorn and Kamoun 2008). Engineering effector targets to promote perception of diverse pathogens could potentially provide a novel avenue for generating broad-spectrum resistance. For instance, a recent study showed that resistance could be engineered against multiple bacterial strains and viral pathogens simply by modifying the protease cleavage sites of PBS1 to serve as substrates for effectors from each of those pathogens (Kim et al. 2016).

Pathogen effector-dependent disruption of interactions between $\mathrm{R}$ proteins and other host proteins that promote $\mathrm{R}$ protein stability and/or resistance signaling, can also contribute to $\mathrm{R}$ protein activation. For example, the coat protein $(\mathrm{CP})$ effector of TCV inhibits the interaction between the R protein HRT and doublestranded RNA-binding protein (DRB) 4, which is required for HRT stability and its derived resistance (Zhu et al. 2013). Likewise, the bacterial effector AvrRps4, inhibits the interaction between EDS1 (Enhanced Disease Susceptibility 1, Wiermer et al. 2005) and a repressor of AvrRps4-triggered immunity (Kwon et al. 2009, Bhattacharjee et al. 2011). EDS1 is a well-known regulator of signaling derived from TIR type of NLR proteins and the defenserelated phytohormone salicylic acid (SA). EDS1 is also important for resistance signaling by some CC type of NLR proteins, where it functions redundantly with SA (Cui et al. 2017; Venugopal et al. 2009). Notably, EDS1 physically interacts with the CC type of NLR, HRT (HR to Turnip crinkle virus) and is involved in the potentiation of HRT-mediated HR (Zhu et al. 2011). Interestingly, despite physical association between soybean EDS1 orthologs (GmEDS1) and HRT, the GmEDS1 proteins cannot potentiate HRTmediated HR (Wang et al. 2014b). This correlates with only partial complementation of the Arabidopsis eds 1 mutant phenotypes by GmEDS1 proteins. In addition to NLR proteins, EDS1 also interacts with pathogen effectors like AvrRPS4, HopA1, and AvrA1, and is required for the virulence function of AvrA1 (Bhattacharjee et al. 2011; Wang et al. 2014b).

Changes in intracellular localization can also be important for the activation of some NLR proteins. Unlike PRRs, the majority of the known R proteins are intracellular, with some exceptions. Notably, NLR proteins from different plants show diverse localizations and several NLR proteins relocalize to another subcellular compartment in response to pathogen infection. For example, resistance signaling by barley MLA10 involves nuclear relocalization in the presence of pathogen effector (Shen et al. 2007). Likewise, Arabidopsis RPS4 localizes to the nucleus in the presence of the cognate bacterial effector though both nuclear and cytoplasmic fractions of RPS4 are essential for complete resistance (Heidrich et al. 2011). The potato Rx NLR, which localizes to both nucleus and cytoplasm, is activated specifically in the cytoplasm, but not the nucleus (Sacco et al. 2007; Slootweg et al. 2010). Intramolecular interactions and folding states of $\mathrm{Rx}$ are thought to regulate the nucleocytoplasmic distribution of Rx (Slootweg et al. 2010). Several Arabidopsis NLRs localize to the plasma membrane and this is essential for the activation of at least two of these proteins (Gao et al. 2011; Qi et al. 2012). These aspects of $\mathrm{R}$ protein activation maybe important considerations when devising strategies to deploy these for longterm crop protection.

\section{EFFECTOR TARGETS}

Pathogens use sophisticated secretion systems to deliver effectors and other pathogenicity elicitors into plant cells. Prominent examples of bacterial secretion systems include the type II system used for translocating plant cell wall-degrading enzymes by Erwinia and Xanthomonas species (Korotkov et al. 2012), type III system used to deliver effector proteins by Gram-negative bacteria like $P$. syringae (Alfano and Collmer 2004), and the type IV system used by Agrobacterium tumefaciens to transfer T-DNA (Cascales and Christie 2003). Fungal and oomycete pathogens use general secretory pathway as well as specialized structures like haustoria and appressoria (Petre and Kamoun 2014). A single pathogen strain can express and deliver multiple effectors into its host. Unlike PAMPs, which are typically essential for pathogen survival, effectors are presumed to primarily serve as pathogen virulence enhancers; pathogen effectors include proteins that interfere with the host PTI response, promote nutrient acquisition, and enhance pathogen dispersal (Chen et al. 2004; Kim et al. 2005; Shan et al. 2008; van Esse et al. 2007; Xiang et al. 2008). Examples are, the transcription-activator-like (TAL) effectors encoded by the plant pathogenic Xanthomonas and Ralstonia species, and a phytopathogenic fungal-endosymbiont, Burkholderia rhizoxinica (Juillerat et al. 2014; Lange et al. 2014). TAL effectors bind specific DNA sequences in the promoters of host genes and induce host gene transcription to promote pathogen virulence and host susceptibility (Zhang et al. 2015). Examples of such host genes include the SWEET-family of sugar transporters, which function as susceptibility genes (Hutin et al. 2015). Plants counteract TAL effectors by expressing recessive alleles of substrate genes that lack TAL binding sites (Hutin et al. 2015), NLR genes that are independent of TAL activity (Bonas et al. 1993; Schornack et al. 2004), and terminator/executor genes that activate HR and thereby restrict pathogen growth in response to TAL activity (Bogdanove et al. 2010; Tian et al. 2014). Engineering executor genes to serve as targets for nonspecific TAL effectors has been successfully used to enhance resistance against multiple unrelated pathogens in pepper and rice (Hummel et al. 2012; Römer et al. 2007). A similar strategy was used to generate citrus canker resistance in grapefruit (Jia et al. 2016).

\section{SUSCEPTIBILITY GENES}

Whereas $R$ and $P R R$ genes activate resistance, some plant genes promote pathogen infection and colonization, and are thereby termed "susceptibility genes" (van Schie and Takken 2014). Changes to susceptibility genes can result in increased disease resistance (Dangl et al. 2013; Sun et al. 2016; van Schie and Takken 2014; Vincelli 2016; Wang et al. 2014c).

The Mlo genes, which encode plant-specific integral membrane proteins of unknown biochemical function, are classic examples (Devoto et al. 2003). Powdery mildew fungi are thought to utilize MLO proteins to enter host cells (Panstruga 2005). In addition, the MLO2 protein of Arabidopsis is targeted by the HopZ2 effector of Pseudomonas syringae and is required for the virulence function of HopZ2 (Lewis et al. 2012). Naturally occurring mutations in Mlo genes have been linked to powdery mildew resistance in barley, pea, and tomato (Bai et al. 2008; Pavan et al. 2011; Piffanelli et al. 2004) and mutant $m l o$ alleles of barley have long been used for agriculture 
in Europe (Lyngkjaer et al. 2000). Some mlo mutations have also been reported to generate broad-spectrum resistance to powdery mildew fungi in barley and Arabidopsis (Büschges et al. 1997; Consonni et al. 2006). Transcription activator-like effector nuclease (TALEN) induced mutations in three wheat $M L O$ genes was also shown to confer broad-spectrum, heritable resistance to powdery mildew (Wang et al. 2014c).

Viral pathogens are particularly reliant on host proteins for survival, and co-opt numerous host proteins for proliferation. Plant translation factors serve as a case-in-point because most plant pathogenic viruses are RNA viruses and translation of the viral RNA is crucial for its replication. Examples include the eukaryotic translation initiation factors eIF4E and eIF4G (Machado et al. 2017; Sanfaçon 2015). These proteins are part of the translation initiation complex and are involved in cap binding during the mRNA-protein complex assembly. In case of potyviruses the VPg (genome-linked viral protein) protein is thought to recruit the host translation complex for viral genome translation via its interaction with eIF4E, and in some cases eIF4G (Robaglia and Caranta 2006). eIF4E is known to affect systemic spread of other viruses (Contreras-Paredes et al. 2013). Naturally occurring mutations in eIF4E/G have been linked to virus resistance in a range of plants and have been deployed for virus resistance in commercially important crops (Wang and Krishnaswamy 2012). Another example is eukaryotic elongation factor 1 alpha (eEF1A), which is recruited by the replication complexes of many RNA viruses (Li et al. 2009; Nishikiori et al. 2006; Thivierge et al. 2008; Yamaji et al. 2006). eEF1A interacts with different viral proteins and lack of eEF1A or the associated eEF1B can restrict viral replication and disease development (Luan et al. 2016; Sasvari et al. 2011).

The functional redundancy among multiple isoforms of these plant translation factors provides important avenues for developing virus resistant plants without repercussions to the host translation machinery. Altering susceptibility genes could create durable disease resistance because a plethora of host factors contribute to hostparasite compatibility in many pathosystems. This offers many potential gene targets that may require only modest genetic changes for engineering resistance. Furthermore, overcoming changes to susceptibility genes would require the pathogen to gain a new function to replace the lost host factor it was exploiting, a task that is unlikely to be easily accomplished (van Schie and Takken 2014).

\section{PATHOGENICITY GENES}

Besides altering plant genes or their expression, pathogenderived genes have also been exploited to generate resistance. The strategy of using pathogen-derived transgenes is based on the concept of pathogen-derived defense (PDR) (Sanford and Johnston 1985), and involves transgenic expression of a pathogen gene in the host. For instance, expression of Tobacco mosaic virus (TMV) coat protein confers resistance against TMV in tobacco (Abel et al. 1986). The transgenic expression of viral coat protein blocks the disassembly of the infecting virus thereby preventing virus replication and movement. This mechanism of resistance is effective against virions but ineffective against the unencapsidated viral RNA or high inoculation titer. Coat protein-mediated resistance has been demonstrated against number of RNA viruses including Potato virus X, Alfalfa mosaic virus, Cucumber mosaic virus, Tobacco etch virus, Potato mop-top virus, PRSV, and more recently against Tobacco ringspot virus (Cillo and Palukaitis 2014). PDR can also be achieved by expressing defective movement protein, replicase subunits or symptom suppressing viral satellites (Baulcombe 1996; Lomonossoff 1995). Movement protein-mediated resistance is advantageous because it can confer broad-spectrum resistance. For example, expression of a defective TMV-movement protein conferred resistance to tobamo-, cucumo-, potex-, and tobraviruses (Cooper et al. 1995). A peptide-mediated resistance strategy has also been developed that involves expressing a 29-amino-acid-long peptide, which interacts with the nucleoprotein of tospoviruses. Transgenic tobacco plants expressing this peptide exhibited broadspectrum resistance to Tomato spotted wilt virus, Tomato chlorotic spot virus, Groundnut ring spot virus, and Chrysanthemum stem necrosis virus (Rudolph et al. 2003).

There are several other examples where PDR is achieved at the transcript level, and this involves transgene-induced silencing of viral RNA by the host encoded RNA silencing machinery (Baulcombe 1996). This technology has been widely used to develop virus-resistant plants, many of which have been approved for commercial use in various countries (Khalid et al. 2017; Palukaitis 2011). While older technologies relied on expressing full-length/partial viral sequences, newer technologies use very short artificial sequences to knock down viral gene expression. This mitigates the risks associated with transgenic expression of longer viral sequences to some extent (Vincelli 2016). Notable examples include the release of PRSV resistant transgenic papaya expressing the coat protein (CP) of PRSV in Hawaii (Fitch et al. 1992; Fereirra et al. 2002; Gonsalves 2006), and the subsequent development of transgenic papaya with resistance specificity to Asian PRSV strains (Bau et al. 2003). Transgenic papaya varieties with commercial approval are now available in both United States and China (Khalid et al. 2017). Likewise, Plum pox virus (PPV)-resistant plum expressing the $\mathrm{CP}$ or hairpin structures targeting the CP of PPV have been developed (Hily et al. 2007; Ravelonandro et al. 2014; Scorza et al. 2001). The CPexpressing variety is approved for release in the United States (Khalid et al. 2017). Other proteins such as viral replicase or RNA silencing suppressors have also been used as targets in RNAi (RNA interference) approaches to develop viral resistance in various hosts including tomato, banana, citrus fruits, common bean, maize, rice, and wheat (Khalid et al. 2017). Some of the lines have been tested for resistance stability in the field over many generations (Cao et al. 2013; Shimizu et al. 2011; Wang et al. 2016). Potato, squash, bean, pepper, and tomato lines have been cleared or approved for release in the United States, Brazil, and China (Aragao et al. 2013; Khalid et al. 2017). The RNAi strategy has also been effectively used to develop resistance against a DNA virus in cassava (Vanderschuren et al. 2007). Increased resistance durability and broader spectrum efficacy has been achieved by targeting multiple viral proteins or using chimeric constructs to simultaneously target multiple pathogens (Gal-On et al. 2005; Lin et al. 2012; Wu et al. 2010).

Plant expressed RNAi constructs against pathogen-derived genes have also been used to enhance resistance against fungal and oomycete pathogens. However, unlike viruses, efficacy of this strategy against fungi or oomycetes requires transport/uptake of host miRNA (microRNA) across the pathogen cell membrane. Indeed, a recent study showed that cotton plants export miRNA into fungal hyphae and specifically target genes that are essential for fungal virulence in the plant (Zhang et al. 2016). Successful examples of resistance induced against fungi and oomycete include, wheat plants expressing RNAi constructs targeting fungal chitin synthase or $\beta$-1,3-glucan synthase that exhibit resistance to Fusarium species (Chen et al. 2016; Cheng et al. 2015). Host-induced silencing of predicted pathogenicity genes or haustorial-enriched genes from the rust fungus Puccinia triticina suppressed rust symptoms in wheat (Panwar et al. 2013; Yin et al. 2015). Notably, host-induced silencing of a Blumeria graminis Avr effector reduced haustoria formation in barley plants lacking the cognate $R$ gene (Nowara et al. 2010).

\section{SYSTEMIC ACOUIRED RESISTANCE}

In addition to local responses, plants also induce systemic responses that provide pathogen resistance at the whole plant level. One such mechanism, which is induced in response to primary infection by a pathogen, is referred to as systemic acquired resistance 
(SAR). SAR involves the generation of signal(s) in the local tissue (site of primary infection), and this occurs very rapidly; within 4 to $6 \mathrm{~h}$ of primary infection. The signal(s) then translocate acropetally likely via the phloem, where they arm the distal uninfected tissue against subsequent secondary pathogen infections (Fu and Dong 2013; Gao et al. 2015; Kachroo and Robin 2013; Shah and Zeier 2013; Wendehenne et al. 2014). This requires careful and balanced cross-talk between various phytohormones, metabolites, and proteins (Pieterse et al. 2012). SAR can also be retained as a memory to be passed on to the next generation of progeny (Luna et al. 2012; Slaughter et al. 2012). Thus, SAR is highly desirable for crop protection because it involves the generation of long-lasting, broadspectrum resistance at the whole plant level. Remarkably, SAR has been reported to confer a fitness advantage under conditions of high disease pressure even though the induction of SAR is associated with negative growth repercussions (Traw et al. 2007).

Several crucial aspects of SAR signaling have been elucidated in the last decade, although much also remains unknown. Several chemical inducers of SAR have been identified; some of which are known to translocate systemically. These include, SA and its methylated derivative MeSA (Durrant and Dong 2004; Park et al. 2007), azelaic acid (AzA) (Jung et al. 2009), glycerol-3-phosphate (G3P) (Chanda et al. 2011), pipecolic acid (Pip) (Návarova et al. 2012), dehydroabietinal (DA) (Chaturvedi et al. 2012), and the free radicals nitric oxide (NO) and reactive oxygen species (ROS) (Wang et al. 2014a). Recent studies show that AzA, G3P, NO, and ROS function in a linear, but feedback-regulated branch, which functions parallel to a second SA-regulated branch, to activate SAR. DA and Pip likely feed into the SA-dependent branch of the SAR pathway because they induce SA accumulation (Bernsdorff et al. 2016; Chaturvedi et al. 2012; Návarova et al. 2012,). The SAR-inducing abilities of many of these chemicals require the nonspecific lipid transfer-like protein (LTP), DIR1 (defective in induced resistance) (Maldonado et al. 2002) and the hybrid proline-rich protein, AZI1 (AzA insensitive) (Cecchini et al. 2015; Jung et al. 2009,). SAR induction also requires "perception" of the mobile signal(s) in the distal tissue. Though some factors essential for signal perception have been identified, this aspect of SAR is not yet well understood. For instance, SAR induction is dependent on the distal tissue having an intact cuticle, a hydrophobic barrier comprising wax and cutin monomers that surrounds all aerial surfaces of the plant (Gao et al. 2015; Lim et al. 2016; Xia et al. 2009, 2010). Plants that are defective in cuticle biosynthesis can generate the SAR signal but are unable to perceive it. In addition, some cuticular components also contribute to SAR mobile signal generation (Xia et al. 2012). This is also true of the major plant lipid, digalactosyl diacylglycerol (DGDG), which contributes to both signal generation and perception. A hallmark of SAR signaling is the significant amount of cross-regulation among the various SAR signaling components. For example, the parallel functioning of the SA- and AzA/G3P-derived branches, the feedback regulatory loop between G3P and DIR1/AZI1, the involvement of DGDG in signal generation and perception, and the inhibition of intracellular movement of AzA and G3P by SA (Lim et al. 2016). All these mechanisms likely promote a finer control of SAR induction to reduce its implications on normal growth particularly since many of the signaling molecules are conserved and essential primary metabolites.

Despite its obviously desirable traits, SAR has not been used in crop protection likely because key advances in our understanding SAR have only been made more recently. It is important to note that although exogenous SA application is widely marketed as an SAR inducer, whole plant chemical applications technically induce local, rather than systemic resistance. SA (and its functional analogs), which is well known to induce broad-spectrum resistance, is marketed commercially as both a pesticide (e.g., Actigard) and a growth stimulant (e.g., AgriGro Ultra). However, SA application typically negatively affects plant productivity due to constitutive reallocation of growth resources to defense responses. In addition to SA, transgenic expression of NPR1 (nonexpressor of pathogenesis related 1), the SA receptor and central regulator of SA responses, is well known to induce broad-spectrum resistance (Fu and Dong 2013; Yan and Dong 2014). Expression of NPR1 was shown to confer resistance to multiple diverse pathogens in Arabidopsis and has been subsequently applied in countless species like wheat, cotton, rice, brassicas, peanut, citrus, strawberry, apple, etc. (Cao et al. 1998; Chen et al. 2012; Dutt et al. 2015; Joshi et al. 2017; Makandar et al. 2006; Molla et al. 2016; Sadumpati et al. 2013; Silva et al. 2015). However, NPR1-expressing transgenic plants have not yet been used in commercial agriculture. Further understanding of the nuances of SAR signaling is key for its applicability in crop production because constitutive induction of SAR or indeed any type of defense is undesirable.

\section{CONCLUSIONS}

Significant advances in our understanding of how plants perceive pathogens and the elucidation of key molecular events underlying defense activation present several novel avenues for generating pathogen resistance in the field. Despite these advances, commercial adaptation of research-based strategies has been limited to the deployment of $R$ genes, natural variants in susceptibility genes, and transgene-induced silencing of pathogen-derived factors. The durability and applicability of usable strategies is constantly challenged by the emergence of resistance breaking pathogen strains, negative repercussions to agronomic traits and yield potential, endurance under adverse environmental conditions, impact to the environment, and public acceptance of strategies involving genetic manipulations. While the use of elite genome editing tools could help alleviate concerns associated with genetic manipulations, further dissection of plant defense pathways is needed to identify factors that are not under evolutionary pressure for change and can be altered to enhance resistance without affecting growth, yield, nutritional value, etc. Understanding how pathogen defense responses interface with primary metabolism, growth and development, abiotic stress responses, and interactions with beneficial organisms, would also be important for developing long-lasting and sustainable plant protection strategies.

\section{ACKNOWLEDGMENTS}

We thank all members (past and present) of the laboratories of A. Kachroo and P. Kachroo who contributed to SAR-related work. Our work is funded by the National Science Foundation (IOS 0749731, 051909), Kentucky Soybean Board, and the Kentucky Science and Engineering Foundation (KSF-2923-RDE-016). The information reported in this article is part of a project of the Kentucky Agricultural Experiment Station and is published with the approval of the Director.

\section{LITERATURE CITED}

Abel, P. P., Nelson, R. S., De, B., Hoffmann, N., Rogers, S. G., Fraley, R. T. 1986. Delay of disease development in transgenic plants that express the Tobacco mosaic virus coat protein gene. Science 232:738-743.

Alfano, J., and Collmer, A. 2004. Type III secretion system effector proteins: Double agents in bacterial disease and plant defense. Annu. Rev. Phytopathol. 42:385-414.

Aragao, F. J. L., Nogueira, E. O. P. L., Tinoco, M. L. P., and Faria, J. C. 2013. Molecular characterization of the first commercial transgenic common bean immune to the Bean golden mosaic virus. J. Biotechnol. 166:42-50.

Ashikawa, I., Hayashi, N., Yamane, H., Kanamori, H., Wu, J., Matsumoto, T., Ono, K., and Yano, M. 2008. Two adjacent nucleotide-binding site-leucine-rich repeat class genes are required to confer pikm-specific rice blast resistance. Genetics 180:2267-2276. 
Axtell, M. J., and Staskawicz, B. J. 2003. Initiation of RPS2-specified disease resistance in Arabidopsis is coupled to the AvrRpt2-directed elimination of RIN4. Cell 112:369-377.

Bai, Y., Pavan, S., Zheng, Z., Zappel, N. F., Reinstädler, A., Lotti, C., De Giovanni, C., Ricciardi, L., Lindhout, P., Visser, R., Theres, K., and Panstruga, R. 2008. Naturally occurring broad-spectrum powdery mildew resistance in a Central American tomato accession is caused by loss of $\mathrm{mlo}$ function. Mol. Plant-Microbe Interact. 21:30-39.

Bau, H. J., Cheng, Y. I. H., Yu, T. A., Yang, J. S., and Yeh, S. D. 2003. Broadspectrum resistance to different geographic strains of Papaya ringspot virus in coat protein gene transgenic papaya. Phytopathology 93:112-120.

Baulcombe, D. C. 1996. Mechanisms of pathogen-derived resistance to viruses in transgenic plants. Plant Cell 8:1833-1844.

Bernsdorff, F., Doering, A. C., Gruner, K., Schuck, S., Bräutigam, A., and Zeier, J. 2016. Pipecolic acid orchestrates plant systemic acquired resistance and defense priming via salicylic acid dependent and independent pathways. Plant Cell 28:102-129.

Bhattacharjee, S., Halane, M. K., Kim, S. H., and Gassmann, W. 2011. Pathogen effectors target Arabidopsis EDS1 and alter its interactions with immune regulators. Science 334:1405-1408.

Bigeard, J., Colcombet, J., and Hirt, H. 2015. Signaling mechanisms in pattern-triggered immunity (PTI). Mol. Plant 8:521-539.

Bogdanove, A. J., Schornack, S., and Lahaye, T. 2010. TAL effectors: Finding plant genes for disease and defense. Curr. Opin. Plant Biol. 13:394-401.

Bonas, U., Conradsstrauch, J., and Balbo, I. 1993. Resistance in tomato to Xanthomonas campestris pv. vesicatoria is determined by alleles of the pepper-specific avirulence gene $a v r B s 3$. Mol. Gen. Genet. 238:261-269.

Brotman, Y., Normantovich, M., Goldenberg, Z., Zvirin, Z., Kovalski, I., Stovbun, N., Doniger, T., Bolger, A. M., Troadec, C., Bendahmane, A., Cohen, R., Katzir, N., Pitrat, M., Dogimont, C., and Perl-Treves, R. 2012. Dual resistance of melon to Fusarium oxysporum races 0 and 2 and to Papaya ring spot virus is controlled by a pair of head-to-head-oriented NBLRR genes of unusual architecture. Mol. Plant 6:235-238.

Büschges, R., Hollricher, K., Panstruga, R., Simons, G., Wolter, M., Frijters, A., van Daelen, R., van der Lee, T., Diergaarde, P., Groenendijk, J., Töpsch, S., Vos, P., Salamini, F., and Schulze-Lefert, P. 1997. The barley Mlo gene: A novel control element of plant pathogen resistance. Cell 88:695-705.

Cao, H., Li, X., and Dong, X. 1998. Generation of broad-spectrum disease resistance by overexpression of an essential regulatory gene in systemic acquired resistance. Proc. Natl. Acad. Sci. USA 95:6531-6536.

Cao, X., Lu, Y. G., Di, D. P., Zhang, Z. Y., Liu, H., Tian, L. Z., Zhang, A., Zhang, Y., Shi, L., Guo, B., Xu, J., Duan, X., Wang, X., Han, C., Miao, H., $\mathrm{Yu}$, J., and Li, D. 2013. Enhanced virus resistance in transgenic maize expressing a dsRNA-specific endoribonuclease gene from E. coli. PLoS One 8:e60829.

Cascales, E., and Christie, P. J. 2003. The versatile bacterial type IV secretion systems. Nat. Rev. Microbiol. 1:137-149.

Cecchini, N. M., Steffes, K., Schlappi, M. R., Gifford, A. N., and Greenberg, J. T. 2015. Arabidopsis AZI1 family proteins mediate signal mobilization for systemic defense priming. Nat. Commun. 6:7658.

Césari, S., Kanzaki, H., Fujiwara, T., Bernoux, M., Chalvon, V., Kawano, Y., Shimamoto, K., Dodds, P., Terauchi, R., and Kroj, T. 2014. The NB-LRR proteins RGA4 and RGA5 interact functionally and physically to confer disease resistance. EMBO J. 33:1941-1959.

Cesari, S., Thilliez, G., Ribot, C., Chalvon, V., Michel, C., Jauneau, A., Rivas, S., Alaux, L., Kanzaki, H., Okuyama, Y., Morel, J.-B., Fournier, E., Tharreau, D., Terauchi, R., and Kroj, T. 2013. The rice resistance protein pair RGA4/RGA5 recognizes the Magnaporthe oryzae effectors AVR-Pia and AVR1-CO39 by direct binding. Plant Cell 25:1463-1481.

Chanda, B., Xia, Y., Mandal, M. K., Yu, K., Sekine, K. T., Gao, Q. M., Selote, D., Hu, Y., Stromberg, A., Navarre, D., Kachroo, A., and Kachroo, P. 2011. Glycerol-3- phosphate, a critical mobile inducer of systemic immunity in plants. Nat. Genet. 43:421-427.

Chaturvedi, R., Venables, B., Petros, R. A., Nalam, V., Li, M., Wang, X., Takemoto, L. J., and Shah, J. 2012. An abietane diter-penoid is a potent activator of systemic acquired resistance. Plant J. 71:161-172.

Chen, W., Kastner, C., Nowara, D., Oliveira-Garcia, E., Rutten, T., Zhao, Y., Deising, H. B., Kumlehn, J., and Schweizer, P. 2016. Host-induced silencing of Fusarium culmorum genes protects wheat from infection. J. Exp. Bot. 67:4979-4991.

Chen, X. K., Zhang, J. Y., Zhang, Z., Du, X. L., Du, B. B., and Qu, S. C. 2012. Overexpressing MhNPR1 in transgenic Fuji apples enhances resistance to apple powdery mildew. Mol. Biol. Rep. 39:8083-8089.

Chen, Z., Kloek, A. P., Cuzick, A., Moeder, W., Tang, D., Innes, R. W., Klessig, D. F., McDowell, J. M., and Kunkel, B. N. 2004. The Pseudomonas syringae type III effector AvrRpt 2 functions downstream or independently of SA to promote virulence on Arabidopsis thaliana. Plant J. 37:494-504.
Cheng, W., Song, X. S., Li, H. P., Cao, L. H., Sun, K., Qiu, X. L., Xu, Y. B., Yang, P., Huang, T., Zhang, J. B., Qu, B., and Liao, Y. C. 2015. Hostinduced gene silencing of an essential chitin synthase gene confers durable resistance to Fusarium head blight and seedling blight in wheat. Plant Biotechnol. J. 13:1335-1345.

Chisholm, S. T., Coaker, G., Day, B., and Staskawicz, B. J. 2006. Host-microbe interactions: Shaping the evolution of the plant immune response. Cell 124: 803-814.

Cillo, F., and Palukaitis, P. 2014. Transgenic resistance. Adv. Virus Res. 90: 35-146.

Consonni, C., Humphry, M. E., Hartmann, H. A., Livaja, M., Durner, J., Westphal, L., Vogel, J., Lipka, V., Kemmerling, B., Schulze-Lefert, P., Somerville, S. C., and Panstruga, R. 2006. Conserved requirement for a plant host cell protein in powdery mildew pathogenesis. Nat. Genet. 38: 716-720.

Contreras-Paredes, C. A., Silva-Rosales, L., Daròs, J. A., Alejandri-Ramírez, N. D., and Dinkova, T. D. 2013. The absence of eukaryotic initiation factor eIF(iso)4E affects the systemic spread of a Tobacco etch virus isolate in Arabidopsis thaliana. Mol. Plant-Microbe Interact. J. 26:461-470.

Cooper, B., Lapidot, M., Heick, J. A., Dodds, J. A., and Beachy, R. N. 1995. A defective movement protein of TMV in transgenic plants confers resistance to multiple viruses whereas the functional analog increases susceptibility. Virology 206:307-313.

Cui, H., Gobbato, E., Kracher, B., Qiu, J., Bautor, J., and Parker, J. E. 2017. A core function of EDS1 with PAD4 is to protect the salicylic acid defense sector in Arabidopsis immunity. New Phytol. 213:1802-1817.

Dangl, J. L., Horvath, D. M., and Staskawicz, B. J. 2013. Pivoting the plant immune system from dissection to deployment. Science 341:746-751.

Devoto, A., Hartmann, H. A., Piffanelli, P., Elliott, C., Simmons, C., Taramino, G., Goh, C. S., Cohen, F. E., Emerson, B. C., Schulze-Lefert, P., and Panstruga, R. 2003. Molecular phylogeny and evolution of the plantspecific seven-transmembrane MLO family. J. Mol. Evol. 56:77-88.

Dodds, P. N., Lawrence, G. J., Catanzariti, A. M., Teh, T., Wang, C. I., Ayliffe, M. A., Kobe, B., and Ellis, J. G. 2006. Direct protein interaction underlies gene-for-gene specificity and coevolution of the flax resistance genes and flax rust avirulence genes. Proc. Natl. Acad. Sci. USA 103:8888-8893.

Durrant, W. E., and Dong, X. 2004. Systemic acquired resistance. Annu. Rev. Phytopathol. 42:185-209.

Dutt, M., Barthe, G., Irey, M., and Grosser, J. 2015. Transgenic citrus expressing an Arabidopsis NPR1 gene exhibit enhanced resistance against Huanglongbing (HLB; citrus greening). PLoS One 10:e0137134.

Ferreira, S. A., Pitz, K. Y., Manshardt, R., Zee, F., Fitch, M., and Gonsalves, D. 2002. Virus coat protein transgenic papaya provides practical control of Papaya ringspot virus in Hawaii. Plant Dis. 86:101-105.

Fitch, M. M. M., Manshardt, R. M., Gonsalves, D., Slightom, J. L., and Sanford, J. C. 1992. Virus resistant papaya plants derived from tissues bombarded with the coat protein gene of Papaya ringspot virus. Nat. Biotechnol. 10:1466-1472.

Flor, H. 1971. Current status of gene-for-gene concept. Annu. Rev. Phytopathol. 9:275-296.

Fradin, E. F., Abd-El-Haliem, A., Masini, L., van den Berg, G. C., Joosten, M. H., and Thomma, B. P. 2011. Interfamily transfer of tomato Ve1 mediates Verticillium resistance in Arabidopsis. Plant Physiol. 156:2255-2265.

$\mathrm{Fu}$, Z. Q., and Dong, X. 2013. Systemic acquired resistance: Turning local infection into global defense. Annu. Rev. Plant Biol. 64:839-863.

Gal-On, A., Wolf, D., Antignus, Y., Patlis, L., Ryu, K. H., Min, B. E., Pearlsman, M., Lachman, O., Gaba, V., Wang, Y., Shiboleth, Y. M., Yang, J., and Zelcer, A. 2005. Transgenic cucumbers harboring the 54-kDa putative gene of Cucumber fruit mottle mosaic tobamovirus are highly resistant to viral infection and protect non-transgenic scions from soil infection. Transgenic Res. 14:81-93.

Gao, Q. M., Zhu, S., Kachroo, P., and Kachroo, A. 2015. Signal regulators of systemic acquired resistance. Front. Plant Sci. 6:228.

Gao, Z., Chung, E.-H., Eitas, T. K., and Dangl, J. L. 2011. Plant intracellular innate immune receptor resistance to Pseudomonas syringae pv. maculicola 1 (RPM1) is activated at, and functions on, the plasma membrane. Proc. Natl. Acad. Sci. USA 108:7619-7624.

Gassmann, W., Hinsch, M. E., and Staskawicz, B. J. 1999. The Arabidopsis RPS4 bacterial resistance gene is a member of the TIR-NBS-LRR family of disease-resistance genes. Plant J. 20:265-77.

Gonsalves, D. 2006. Transgenic papaya: Development, release, impact and challenges. Adv. Virus Res. 67:317-354.

Heidrich, K., Wirthmueller, L., Tasset, C., Pouzet, C., Deslandes, L., and Parker, J. E. 2011. Arabidopsis EDS1 connects pathogen effector recognition to cell compartment-specific immune responses. Science 334:14011404.

Hily, J. M., Ravelonandro, M., Damsteegt, V., Bassett, C., Petri, C., Liu, Z., and Scorza, R. 2007. Plum pox virus coat protein gene intron-hairpin-RNA 
(ihpRNA) constructs provide resistance to Plum pox virus in Nicotiana benthamiana and Prunus domestica. J. Am. Soc. Hortic. Sci. 132:850-858.

Holliday, M. J., Keen, N. T., and Long, M. 1981. Cell death patterns and accumulation of fluorescent material in the hypersensitive response of soybean leaves to Pseudomonas syringae pv. glycinea. Physiol. Plant Pathol. 18:279-287.

Horvath, D. M., Stall, R. E., Jones, J. B., Pauly, M. H., Vallad, G. E., Dahlbeck, D., Staskawicz, B. J., and Scott, J. W. 2012. Transgenic resistance confers effective field level control of bacterial spot disease in tomato. PLoS One 7: e42036.

Hummel, A. W., Doyle, E. L., and Bogdanove, A. J. 2012. Addition of transcription activator-like effector binding sites to a pathogen strain-specific rice bacterial blight resistance gene makes it effective against additional strains and against bacterial leaf streak. New Phytol. 195:883-893.

Hutin, M., Pérez-Quintero, A. L., Lopez, C., and Szurek, B. 2015. MorTAL Kombat: The story of defense against TAL effectors through loss-ofsusceptibility. Front. Plant Sci. 6:535.

Innes, R. 2004. Guarding the goods; New insights into the central alarm system of plants. Plant Physiol. 135:695-701.

Jia, H., Orbovic, V., Jones, J. B., and Wang, N. 2016. Modification of the PthA4 effector binding elements in Type I CsLOB1 promoter using Cas9/ sgRNA to produce transgenic Duncan grapefruit alleviating XccDpthA4: dCsLOB1.3 infection. Plant Biotechnol. J. 14:1291-1301.

Jones, J. D., and Dangl, J. L. 2006. The plant immune system. Nature 444: 323-329.

Joshi, S. G., Kumar, V., Janga, M. R., Bell, A. A., and Rathore, K. S. 2017. Response of AtNPR1-expressing cotton plants to Fusarium oxysporum f. sp. vasinfectum isolates. Physiol. Mol. Biol. Plants 23:135-142.

Juillerat, A., Bertonati, C., Dubois, G., Guyot, V., Thomas, S., Valton, J., Beurdeley, M., Silva, G. H., Daboussi, F., and Duchateau, P. 2014. BurrH: A new modular DNA binding protein for genome engineering. Sci. Rep. 4: 3831.

Jung, H. W., Tschaplinski, T. J., Wang, J., Glazebrook, J., and Greenberg, J. T. 2009. Priming in systemic plant immunity. Science 324:89-91.

Kachroo, A., and Kachroo, P. 2007. Salicylic acid-, jasmonic acid- and ethylene-mediated regulation of plant defense signaling. Genet. Eng. (N.Y.) 28:55-83.

Kachroo, A., and Robin, G. P. 2013. Systemic signaling during plant defense. Curr. Opin. Plant Biol. 16:527-533.

Kanzaki, H., Yoshida, K., Saitoh, H., Fujisaki, K., Hirabuchi, A., Allaux, L., Fournier, E., Tharreau, D., and Terauchi, R. 2012. Arms race co-evolution of Magnaporthe oryzae AVR-Pik and rice Pik genes driven by their physical interactions. Plant J. 72:894-907.

Kawashima, C. G., Guimaraes, G. A., Nogueira, S. R., MacLean, D., Cook, D. R., Steuernagel, B., Baek, J., Bouyioukos, C., Melo, B., Tristao, G., de Oliveira, J. C., Rauscher, G., Mittal, S., Panichelli, L., Bacot, K., Johnson, E., Iyer, G., Tabor, G., Wulff, B. B. H., Ward, E., Rairdan, G. J., Broglie, K. E., Wu, G., van Esse, H. P., Jones, J. D. G., and Brommonschenkel, S. H. 2016. A pigeonpea gene confers resistance to Asian soybean rust in soybean. Nat. Biotechnol. 34:661-665.

Khalid, A., Zhang, Q., Yasir, M., and Li, F. 2017. Small RNA based genetic engineering for plant viral resistance: Application in crop protection. Front. Microbiol. 8:43.

Kim, M. G., da Cunha, L., McFall, A. J., Belkhadir, Y., DebRoy, S., Dangl, J. L., and Mackey, D. 2005. Two Pseudomonas syringae type III effectors inhibit RIN4-regulated basal defense in Arabidopsis. Cell 121:749-759.

Kim, S. H., Qi, D., Ashfield, T., Helm, M., and Innes, R. W. 2016. Using decoys to expand the recognition specificity of a plant disease resistance protein. Science 351:684-687.

Koeppel, D. 2008. Banana: The Fate of the Fruit That Changed the World. Penguin Books, New York.

Korotkov, K. V., Sandkvist, M., and Hol, W. G. J. 2012. The type II secretion system: Biogenesis, molecular architecture and mechanism. Nat. Rev. Microbiol. 10:336-351.

Krasileva, K. V., Dahlbeck, D., and Staskawicz, B. J. 2010. Activation of an Arabidopsis resistance protein is specified by the in planta association of its leucine-rich repeat domain with the cognate oomycete effector. Plant Cell 22:2444-2458

Kwon, S. I., Kim, S. H., Bhattacharjee, S., Noh, J. J., and Gassmann, W. 2009. SRFR1, a suppressor of effector-triggered immunity, encodes a conserved tetratricopeptide repeat protein with similarity to transcriptional repressors. Plant J. 57:109-119.

Lacombe, S., Rougon-Cardoso, A., Sherwood, E., Peeters, N., Dahlbeck, D., van Esse, H. P., Smoker, M., Rallapalli, G., Thomma, B. P., Staskawicz, B., Jones, J. D., and Zipfel, C. 2010. Interfamily transfer of a plant patternrecognition receptor confers broad-spectrum bacterial resistance. Nat. Biotechnol. 28:365-369.
Lange, O. D., Wolf, C., Dietze, J., Elsaesser, J., Morbitzer, R., and Lahaye, T. 2014. Programmable DNA-binding proteins from Burkholderia provide a fresh perspective on the TALE-like repeat domain. Nucleic Acids Res. 42: 7436-7449.

Lee, S.-K., Song, M.-Y., Seo, Y.-S., Kim, H.-K., Ko, S., Cao, P.-J., Suh, J.-P., Yi, G., Roh, J.-H., Lee, S., An, G., Hahn, T.-R., Wang, G.-L., Ronald, P., and Jeon, J.-S. 2009. Rice Pi5-mediated resistance to Magnaporthe oryzae requires the presence of two coiled-coil-nucleotide-binding-leucine-rich repeat genes. Genetics 181:1627-1638.

Lewis, J. D., Wan, J., Ford, R., Gong, Y., Fung, P., Nahal, H., Wang, P. W., Desveaux, D., and Guttman, D. S. 2012. Quantitative interactor screening with next-generation sequencing (QIS-Seq) identifies Arabidopsis thaliana MLO2 as a target of the Pseudomonas syringae type III effector HopZ2. BMC Genomics 13:8.

Li, Z., Pogany, J., Panavas, T., Xu, K., Esposito, A. M., Kinzy, T. G., and Nagy, P. D. 2009. Translation elongation factor $1 \mathrm{~A}$ is a component of the tombusvirus replicase complex and affects the stability of the p33 replication co-factor. Virology 385:245-260.

Lim, G. H., Shine, M. B., de Lorenzo, L., Yu, K., Cui, W., Navarre, D., Hunt, A. G., Lee, J. Y., Kachroo, A., and Kachroo, P. 2016. Plasmodesmata localizing proteins regulate transport and signaling during systemic acquired immunity in plants. Cell Host Microbe 19:541-549.

Lin, C. Y., Ku, H. M., Chiang, Y. H., Ho, H. Y., Yu, T. A., and Jan, F. J. 2012. Development of transgenic watermelon resistant to Cucumber mosaic virus and Watermelon mosaic virus by using a single chimeric transgene construct. Transgenic Res. 21:983-993.

Lomonossoff, G. P. 1995. Pathogen-derived resistance to plant viruses. Annu. Rev. Phytopathol. 33:323-343.

Loutre, C., Wicker, T., Travella, S., Galli, P., Scofield, S., Fahima, T., Feuillet, C., and Keller, B. 2009. Two different CC-NBS-LRR genes are required for Lr10-mediated leaf rust resistance in tetraploid and hexaploid wheat. Plant J. 60:1043-1054

Luan, H., Shine, M. B., Cui, X., Chen, X., Ma, N., Kachroo, P., Zhi, H., and Kachroo, A. 2016. The potyviral P3 protein targets eukaryotic elongation factor 1A to promote the unfolded protein response and viral pathogenesis. Plant Physiol. 172:221-234.

Luna, E., Bruce, T. J. A., Roberts, M. R., Flors, V., and Ton, J. 2012. Next generation systemic acquired resistance. Plant Physiol. 158:844-853.

Luo, Y., Caldwell, K. S., Wroblewski, T., Wright, M. E., and Michelmore, R. W. 2009. Proteolysis of a negative regulator of innate immunity is dependent on resistance genes in tomato and Nicotiana benthamiana and induced by multiple bacterial effectors. Plant Cell 21:2458-2472.

Lyngkjaer, M. F., Newton, A. C., Atzema, J. L., and Baker, S. J. 2000. The barley mlo-gene: An important powdery mildew resistance source. Agronomie 20:745-756.

Machado, J. P., Calil, I. P., Santos, A. A., and Fontes, E. P. 2017. Translational control in plant antiviral immunity. Genet. Mol. Biol. 40:292-304.

Mackey, D., Belkhadir, Y., Alfonso, J. M., Ecker, J. R., and Dangl, J. L. 2003. Arabidopsis RIN4 is a target of the type III virulence effector AvrRpt2 and modulates RPS2-mediated resistance. Cell 112:379-389.

Mackey, D., Holt, B. F., III, Wiig, A., and Dangl, J. L. 2002. RIN4 interacts with Pseudomonas syringae type III effector molecules and is required for RPM1-mediated resistance in Arabidopsis. Cell 108:743-754.

Maekawa, T., Kracher, B., Vernaldi, S., Ver Loren van Themaat, E., and Schulze-Lefert, P. 2012. Conservation of NLR-triggered immunity across plant lineages. Proc. Natl. Acad. Sci. USA 109:20119-20123.

Maekawa, T., Kufer, T. A., and Schulze-Lefert, P. 2011. NLR functions in plant and animal immune systems: So far and yet so close. Nat. Immunol. 12:817-826.

Makandar, R., Essig, J. S., Schapaugh, M. A., Trick, H. N., and Shah, J. 2006. Genetically engineered resistance to Fusarium head blight in wheat by expression of Arabidopsis NPR1. Mol. Plant-Microbe Interact. 19:123-129.

Maldonado, A. M., Doerner, P., Dixon, R. A., Lamb, C. J., and Cameron, R. K. 2002. A putative lipid transfer protein involved in systemic acquired resistance signaling in Arabidopsis. Nature 419:399-403.

Martin, G. B., Bogdanove, A. J., and Sessa, G. 2003. Understanding the functions of plant disease resistance proteins. Annu. Rev. Plant Biol. 54: 23-61.

Moffett, P., Farnham, G., Peart, J., and Baulcombe, D. C. 2002. Interaction between domains of a plant NBS-LRR protein in disease resistance-related cell death. EMBO J. 21:4511-4519.

Molla, K. A., Karmakar, S., Chanda, P. K., Sarkar, S. N., Datta, S. K., and Datta, K. 2016. Tissue-specific expression of Arabidopsis NPR1 gene in rice for sheath blight resistance without compromising phenotypic cost. Plant Sci. 250:105-114.

Monaghan, J., and Zipfel, C. 2012. Plant pattern recognition receptor complexes at the plasma membrane. Curr. Opin. Plant Biol. 15:349-357. 
Narusaka, M., Kubo, Y., Hatakeyama, K., Imamura, J., Ezura, H., Nanasato, Y., Tabei, Y., Takano, Y., Shirasu, K., and Narusaka, Y. 2013. Interfamily transfer of dual NB-LRR genes confers resistance to multiple pathogens. PLoS One 8:e55954.

Narusaka, M., Shirasu, K., Noutoshi, Y., Kubo, Y., Shiraishi, T., Iwabuchi, M., and Narusaka, Y. 2009. RRS1 and RPS4 provide a dual resistance-gene system against fungal and bacterial pathogens. Plant J. 60:218-226.

Návarova, H., Bernsdorff, F., Doring, A. C., and Zeier, J. 2012. Pipecolic acid, an endogenous mediator of defense amplification and priming, is a critical regulator of inducible plant immunity. Plant Cell 24:5123-5141.

Nishikiori, M., Dohi, K., Mori, M., Meshi, T., Naito, S., and Ishikawa, M. 2006. Membrane-bound Tomato mosaic virus replication proteins participate in RNA synthesis and are associated with host proteins in a pattern distinct from those that are not membrane bound. J. Virol. 80:8459-8468.

Nowara, D., Gay, A., Lacomme, C., Shaw, J., Ridout, C., Douchkov, D., Hensel, G., Kumlehn, J., and Schweizer, P. 2010. HIGS: Host-induced gene silencing in the obligate biotrophic fungal pathogen Blumeria graminis. Plant Cell 22:3130-3141.

Okuyama, Y., Kanzaki, H., Abe, A., Yoshida, K., Tamiru, M., Saitoh, H., Fujibe, T., Matsumura, H., Shenton, M., Galam, D. C., Undan, J., Ito, A., Sone, T., and Terauchi, R. 2011. A multifaceted genomics approach allows the isolation of the rice Pia-blast resistance gene consisting of two adjacent NBS-LRR protein genes. Plant J. 66:467-479.

Palukaitis, P. 2011. The road to RNA silencing is paved with plant-virus interactions. Plant Pathol. J. 27:197-206.

Panstruga, R. 2005. Serpentine plant MLO proteins as entry portals for powdery mildew fungi. Biochem. Soc. Trans. 33:389-392.

Panwar, V., McCallum, B., and Bakkeren, G. 2013. Host-induced gene silencing of wheat leaf rust fungus Puccinia triticina pathogenicity genes mediated by the Barley stripe mosaic virus. Plant Mol. Biol. 81:595-608.

Park, S. W., Kaimoyo, E., Kumar, D., Mosher, S., and Klessig, D. F. 2007. Methyl salicylate is a critical mobile signal for plant systemic acquired resistance. Science 318:113-116.

Pavan, S., Schiavulli, A., Appiano, M., Marcotrigiano, A. R., Cillo, F., Visser, R. G., Bai, Y., Lotti, C., and Ricciardi, L. 2011. Pea powdery mildew er1 resistance is associated to loss-of-function mutations at a MLO homologous locus. Theor. Appl. Genet. 123:1425-1431.

Petre, B., and Kamoun, S. 2014. How do filamentous pathogens deliver effector proteins into plant cells? PLoS Biol. 12:e1001801.

Pieterse, C. M. J., Van der Does, D., Zamioudis, C., Leon-Reyes, A., and Van Wees, S. C. M. 2012. Hormonal modulation of plant immunity. Annu. Rev. Cell Dev. Biol. 28:489-521.

Piffanelli, P., Ramsay, L., Waugh, R., Benabdelmouna, A., D'Hont, A., Hollricher, K., Jørgensen, J. H., Schulze-Lefert, P., and Panstruga, R. 2004. A barley cultivation-associated polymorphism conveys resistance to powdery mildew. Nature 430:887-891.

Qi, D., Deyoung, B. J., and Innes, R. W. 2012. Structure-function analysis of the coiled-coil and leucine-rich repeat domains of the RPS5 disease resistance protein. Plant Physiol. 158:1819-1832.

Ravelonandro, M., Scorza, R., Michel, H. J., and Briard, P. 2014. The efficiency of RNA interference for conferring stable resistance to plum pox virus. Plant Cell Tissue Organ Cult. 118:347-356.

Ravensdale, M., Bernoux, M., Ve, T., Kobe, B., Thrall, P. H., Ellis, J. G., and Dodds, P. N. 2012. Intramolecular interaction influences binding of the flax L5 and L6 resistance proteins to their AvrL567 ligands. PLoS Pathog. 8: e1003004.

Robaglia, C., and Caranta, C. 2006. Translation initiation factors: A weak link in plant RNA virus infection. Trends Plant Sci. 11:40-45.

Römer, P., Hahn, S., Jordan, T., Strauss, T., Bonas, U., and Lahaye, T. 2007. Plant pathogen recognition mediated by promoter activation of the pepper Bs3 resistance gene. Science 318:645-648.

Rooney, H. C., Van't Klooster, J. W., van der Hoorn, R. A., Joosten, M. H., Jones, J. D., and de Wit, P. J. 2005. Cladosporium Avr2 inhibits tomato $\mathrm{Rcr} 3$ protease required for $\mathrm{Cf}-2$-dependent disease resistance. Science 308 : 1783-1786.

Rudolph, C., Schreier, P. H., and Uhrig, J. F. 2003. Peptide-mediated broadspectrum plant resistance to tospoviruses. Proc. Natl. Acad. Sci. USA 100: 4429-4434.

Sacco, M. A., Mansoor, S., and Moffett, P. 2007. A RanGAP protein physically interacts with the NB-LRR protein $\mathrm{Rx}$, and is required for Rxmediated viral resistance. Plant J. 52:82-93.

Sadumpati, V., Kalambur, M., Vudem, D. R., Kirti, P. B., and Khareedu, V. R. 2013. Transgenic Indica rice lines, expressing Brassica juncea nonexpressor of pathogenesis-related genes 1 (BjNPR1), exhibit enhanced resistance to major pathogens. J. Biotechnol. 166:114-121.

Sanfaçon, H. 2015. Plant translation factors and virus resistance. Viruses 7: 3392-3419.
Sanford, J. C., and Johnston, S. A. 1985. The concept of parasite-derived resistance-Deriving resistance genes from the parasite's own genome. J. Theor. Biol. 113:395-405.

Sasvari, Z., Izotova, L., Kinzy, T. G., and Nagy, P. D. 2011. Synergistic roles of eukaryotic translation elongation factors $1 \mathrm{Bgamma}$ and $1 \mathrm{~A}$ in stimulation of tombusvirus minus-strand synthesis. PLoS Pathog 7:e1002438.

Saunders, K., Bedford, I. D., Yahara, T., and Stanley, J. 2003. The earliest recorded plant virus disease. Nature 422:831.

Schoonbeek, H. J., Wang, H. H., Stefanato, F. L., Craze, M., Bowden, S., Wallington, E., Zipfel, C., and Ridout, C. J. 2015. Arabidopsis EF-Tu receptor enhances bacterial disease resistance in transgenic wheat. New Phytol. 206:606-613.

Schornack, S., Ballvora, A., Gurlebeck, D., Peart, J., Ganal, M., Baker, B., Bonas, U., and Lahaye, T. 2004. The tomato resistance protein Bs4 is a predicted non-nuclear TIR-NB-LRR protein that mediates defense responses to severely truncated derivatives of AvrBs4 and overexpressed AvrBs3. Plant J. 37:46-60.

Schwessinger, B., Bahar, O., Thomas, N., Holton, N., Nekrasov, V., Ruan, D. 2015. Transgenic expression of the dicotyledonous pattern recognition receptor EFR in rice leads to ligand-dependent activation of defense responses. PLoS Pathog. 11:e1004809.

Schwessinger, B., and Ronald, P. C. 2012. Plant innate immunity: Perception of conserved microbial signatures. Annu. Rev. Plant Biol. 63:451-482.

Scorza, R., Callahan, A., Levy, L., Damsteegt, V., Webb, K., and Ravelonandro, M. 2001. Post-transcriptional gene silencing in plum pox virus resistant transgenic European plum containing the plum pox potyvirus coat protein gene. Transgenic Res. 10:201-209.

Selote, D., and Kachroo, A. 2010. RPG1-B-derived resistance to AvrBexpressing Pseudomonas syringae requires RIN4-like proteins in soybean. Plant Physiol. 153:1199-211.

Selote, D., Robin, G. P., and Kachroo, A. 2013. GmRIN4 protein family members function nonredundantly in soybean race-specific resistance against Pseudomonas syringae. New Phytol. 197:1225-1235.

Shah, J., and Zeier, J. 2013. Long-distance communication and signal amplification in systemic acquired resistance. Front. Plant Sci. 4:30.

Shabab, M., Shindo T., Gu, C., Kaschani, F., Pansuriya, T., Chintha, R., Harzen, A., Colby, T., Kamoun, S., and van der Hoorn, R. A. 2008. Fungal effector protein AVR2 targets diversifying defense-related cys proteases of tomato. Plant Cell 20:1169-1183.

Shan, L., He, P., Li, J., Heese, A., Peck, S.C., Nürnberger, T., Martin, G. B., and Sheen, J. 2008. Bacterial effectors target the common signaling partner BAK1 to disrupt multiple MAMP receptor-signaling complexes and impede plant immunity. Cell H\&M 4:17-27.

Shao, F., Golstein, C., Ade, J., Stoutemyer, M., Dixon, J. E., and Innes, R. W. 2003. Cleavage of Arabidopsis PBS1 by a bacterial type III effector. Science 301:1230-1233.

Shen, Q. H., Saijo, Y., Mauch, S., Biskup, C., Bieri, S., Keller, B., Seki, H., Ulker, B., Somssich, I. E., and Schulze-Lefert, P. 2007. Nuclear activity of MLA immune receptors links isolate-specific and basal disease-resistance responses. Science 315:1098-1103.

Shi, Q., Febres, V. J., Jones, J. B., and Moore, G. A. 2016. A survey of FLS2 genes from multiple citrus species identifies candidates for enhancing disease resistance to Xanthomonas citri ssp. citri. Hortic Res. 3:16022.

Shimizu, T., Nakazono-Nagaoka, E., Uehara-Ichiki, T., Sasaya, T., and Omura, T. 2011. Targeting specific genes for RNA interference is crucial to the development of strong resistance to rice stripe virus. Plant Biotechnol. J. 9:503-512.

Silva, K. J., Brunings, A., Peres, N. A., Mou, Z., and Folta, K. M. 2015. The Arabidopsis NPRl gene confers broad-spectrum disease resistance in strawberry. Transgenic Res. 24:693-704.

Sinapidou, E., Williams, K., Nott, L., Bahkt, S., Tör, M., Crute, I., Bittner-Eddy, P., and Beynon, J. 2004. Two TIR:NB:LRR genes are required to specify resistance to Peronospora parasitica isolate Cala2 in Arabidopsis. Plant J. 38:898-909.

Singh, R. P., Hodson, D. P., Huerta-Espino, J., Jin, Y., Bhavani, S., Njau, P., Herrera-Foessel, S., Singh, P. K., Singh, S., and Govindan, V. 2011. The emergence of $\mathrm{Ug} 99$ races of the stem rust fungus is a threat to world wheat production. Annu. Rev. Phytopathol. 49:465-481.

Slaughter, A., Daniel, X., Flors, V., Luna, E., Hohn, B., and Mauch-Mani, B. 2012. Descendants of primed Arabidopsis plants exhibit resistance to biotic stress. Plant Physiol. 158:835-843.

Slootweg, E., Roosien, J., Spiridon, L. N., Petrescu, A. J., Tameling, W., Joosten, M., Pomp, R., van Schaik, C., Dees, R., Borst, J. W., Smant, G., Schots, A., Bakker, J., and Goverse, A. 2010. Nucleocytoplasmic distribution is required for activation of resistance by the potato NB-LRR receptor $\mathrm{Rx} 1$ and is balanced by its functional domains. Plant Cell 22: 4195-4215. 
Sun, K., Wolters, A. M., Vossen, J. H., Rouwet, M. E., Loonen, A. E., Jacobsen, E., Visser, R. G., and Bai, Y. 2016. Silencing of six susceptibility genes results in potato late blight resistance. Transgenic Res. 25:731-742.

Tai, T. H., Dahlbeck, D., Clark, E. T., Gajiwala, P., Pasion, R., Whalen, M. C., Stall, R. E., and Staskawicz, B. J. 1999. Expression of the Bs2 pepper gene confers resistance to bacterial spot disease in tomato. Proc. Natl. Acad. Sci. 96:14153-14158.

Tameling, W. I., Elzinga, S. D., Darmin, P. S., Vossen, J. H., Takken, F. L., Haring, M. A., and Cornelissen, B. J. 2002. The tomato R gene products I-2 and MI-1 are functional ATP binding proteins with ATPase activity. Plant Cell 14:2929-2939.

Tameling, W. I., Vossen, J. H., Albrecht, M., Lengauer, T., Berden, J. A., Haring, M. A., Cornelissen, B. J., and Takken, F. L. 2006. Mutations in the NB-ARC domain of I-2 that impair ATP hydrolysis cause autoactivation. Plant Physiol. 140:1233-1245.

Thivierge, K., Cotton, S., Dufresne, P. J., Mathieu, I., Beauchemin, C., Ide, C., Fortin, M. G., and Laliberte, J. F. 2008. Eukaryotic elongation factor 1A interacts with Turnip mosaic virus RNA-dependent RNA polymerase and VPg-Pro in virus-induced vesicles. Virology 377:216-225.

Tian, D., Wang, J., Zeng, X., Gu, K., Qiu, C., Yang, X., Zhou, Z., Goh, M., Luo, Y., Murata-Hori, M., White, F. F., and Yin, Z. 2014. The rice TAL effector-dependent resistance protein XA10 triggers cell death and calcium depletion in the endoplasmic reticulum. Plant Cell 26:497-515.

Traw, M. B., Kniskern, J. M., and Bergelson, J. 2007. SAR increases fitness of Arabidopsis thaliana in the presence of natural bacterial pathogens. Evolution 61:2444-2449.

Tripathi, L., Tripathi, J. N., Kiggundu, A., Korie, S., Shotkoski, F., and Tushemereirwe, W. K. 2014. Field trial of Xanthomonas wilt diseaseresistant bananas in East Africa. Nat. Biotechnol. 32:868-870.

Van der Biezen, E. A., and Jones, J. D. 1998. Plant disease-resistance proteins and the gene-for-gene concept. Trends Biochem. Sci. 23:454-456.

van der Hoorn, R. A., and Kamoun, S. 2008. From Guard to Decoy: A new model for perception of plant pathogen effectors. Plant Cell 20:2009-2017.

van der Vossen, E. A. G., Gros, J., Sikkema, A., Muskens, M., Wouters, D., Wolters, P., Pereira, A., and Allefs, S. 2005. The Rpi-blb2 gene from Solanum bulbocastanum is a Mi-1 gene homolog conferring broadspectrum late blight resistance in potato. Plant J. 44:208-222.

van Esse, H. P., Bolton, M. D., Stergiopoulos, I., de Wit, P. J., and Thomma, B. P. 2007. The chitin-binding Cladosporium fulvum effector protein Avr4 is a virulence factor. Mol. Plant-Microbe Interact. 20:1092-1101.

van Schie, C. C., and Takken, F. L. 2014. Susceptibility genes 101: How to be a good host. Annu. Rev. Phytopathol. 52:551-581.

Vanderschuren, H., Akbergenov, R., Pooggin, M. M., Hohn, T., Gruissem, W., and Zhang, P. 2007. Transgenic cassava resistance to African cassava mosaic virus is enhanced by viral DNA-A bidirectional promoter-derived siRNAs. Plant Mol. Biol. 64:549-557.

Venugopal, S. C., Jeong, R.-D., Mandal, M. K., Zhu, S., Chandra-Shekara, Xia, Y., Hersh, M., Stromberg, A. J., Navarre, R., Kachroo, A., and Kachroo, P. 2009. Enhance disease susceptibility 1 and salicylic acid act redundantly to regulate resistance gene-mediated signaling. PLoS Genet. 5:e1000545

Vincelli, P. 2016. Genetic engineering and sustainable crop disease management: Opportunities for case-by-case decision-making. Sustainability 8:495.

Wally, O., and Punja, Z. K. 2010. Genetic engineering for increasing fungal and bacterial disease resistance in crop plants. GM Crops 1:199-206.

Wang, A., and Krishnaswamy, S. 2012. Eukaryotic translation initiation factor 4E-mediated recessive resistance to plant viruses and its utility in crop improvement. Mol. Plant Pathol. 13:795-803.

Wang, C., El-Shetehy, M., Shine, M. B., Yu, K., Navarre, D., Wendehenne, D., Kachroo, A., and Kachroo, P. 2014a. Free radicals mediate systemic acquired resistance. Cell Reports 7:348-355.

Wang, F., Li, W., Zhu, J., Fan, F., Wang, J., Zhong, W., Wang, M.-B., Liu, Q., Zhu, Q.-H., Zhou, T., Lan, Y., Zhou, Y., and Yang, J. 2016. Hairpin RNA targeting multiple viral genes confers strong resistance to Rice blackstreaked dwarf virus. Int. J. Mol. Sci. 17:705.

Wang, J., Shine, M. B., Gao, Q. M., Navarre, D., Jiang, W., Liu, C., Chen, Q., Hu, G., and Kachroo, A. 2014b. Enhanced disease susceptibility 1 mediates pathogen resistance and virulence function of a bacterial effector in soybean. Plant Physiol. 165:1269-1284.

Wang, X., Richards, J., Gross, T., Druka, A., Kleinhofs, A., Steffenson, B., Acevedo, M., and Brueggeman, R. 2013. The rpg4-mediated resistance to wheat stem rust (Puccinia graminis) in barley (Hordeum vulgare) requires Rpg5, a second NBS-LRR gene, and an actin depolymerization factor. Mol. Plant-Microbe Interact. 26:407-418

Wang, Y., Cheng, X., Shan, Q., Zhang, Y., Liu, J., Gao, C., and Qiu, J. L. 2014c. Simultaneous editing of three homoeoalleles in hexaploid bread wheat confers heritable resistance to powdery mildew. Nat. Biotechnol. 32: 947-951.
Wendehenne, D., Gao, Q. M., Kachroo, A., and Kachroo, P. 2014. Free radicalmediated systemic immunity in plants. Curr. Opin. Plant Biol. 20:127-134.

Wiermer, M., Feys, B. J., and Parker, J. E. 2005. Plant immunity: The EDS1 regulatory node. Curr. Opin. Plant Biol. 8:383-389.

Williams, S. J., Sohn, K. H., Wan, L., Bernoux, M., Sarris, P. F., Segonzac, C., Ve, T., Ma, Y., Saucet, S. B., Ericsson, D. J., Casey, L. W., Lonhienne, T., Winzor, D. J., Zhang, X., Coerdt, A., Parker, J. E., Dodds, P. N., Kobe, B., and Jones, J. D. G. 2014. Structural basis for assembly and function of a heterodimeric plant immune receptor. Science 344:299-303.

Williams, S. J., Sornaraj, P., deCourcy-Ireland, E., Menz, R. I., Kobe, B., Ellis, J. G., Dodds, P. N., and Anderson, P. A. 2011. An autoactive mutant of the $\mathrm{M}$ flax rust resistance protein has a preference for binding ATP, whereas wild-type M protein binds ADP. Mol. Plant-Microbe Interact. 24:897-906.

Wu, H. W., Yu, T. A., Raja, J. A. J., Christopher, S. J., Wang, S. L., and Yeh, S. D. 2010. Double-virus resistance of transgenic oriental melon conferred by untranslatable chimeric construct carrying partial coat protein genes of two viruses. Plant Dis. 94:1341-1347.

Xia, Y., Gao, Q. M., Yu, K., Lapchyk, L., Navarre, D., Hildebrand, D., Kachroo, A., and Kachroo, P. 2009. An intact cuticle in distal tissues is essential for the induction of systemic acquired resistance in plants. Cell Host Microbe. 5:151-165

Xia, Y., Yu, K., Gao, Q. M., Wilson, E. V., Navarre, D., Kachroo, P., and Kachroo, A. 2012. Acyl CoA binding proteins are required for cuticle formation and plant responses to microbes. Front. Plant Sci. 3:224

Xia, Y., Yu, K., Navarre, D., Seebold, S., Kachroo, A., and Kachroo, P. 2010. The glabral mutation affects cuticle formation and plant responses to microbes. Plant Physiol. 154:833-846.

Xiang, T., Zong, N., Zou, Y., Wu, Y., Zhang, J., Xing, W., Li, Y., Tang, X., Zhu, L., Chai, J., and Zhou, J. M. 2008. Pseudomonas syringae effector AvrPto blocks innate immunity by targeting receptor kinases. Curr. Biol. 18:74-80.

Yamaji, Y., Kobayashi, T., Hamada, K., Sakurai, K., Yoshii, A., Suzuki, M., Namba, S., and Hibi, T. 2006. In vivo interaction between Tobacco mosaic virus RNA-dependent RNA polymerase and host translation elongation factor 1A. Virology 347:100-108

Yan, S., and Dong, X. 2014. Perception of the plant immune signal salicylic acid. Curr. Opin. Plant Biol. 20:64-68.

Yang, S., Li, J., Zhang, X., Zhang, Q., Huanga, J., Chen, J.-Q., Hart, D. L., and Tiana, D. 2013. Rapidly evolving $\mathrm{R}$ genes in diverse grass species confer resistance to rice blast disease. Proc. Natl. Acad. Sci. USA 110: $18572-18577$

Yang, S. M., Gao, M. Q., Xu, C. W., Gao, J. C., Deshpande, S., Lin, S. P. 2008. Alfalfa benefits from Medicago truncatula: The RCT1 gene from M. truncatula confers broad-spectrum resistance to anthracnose in alfalfa. Proc. Natl. Acad. Sci. USA 105:12164-9.

Yin, C., Downey, S. I., Klages-Mundt, N. L., Ramachandran, S., Chen, X., Szabo, L. J., Pumphrey, M., and Hulbert, S. H. 2015. Identification of promising host-induced silencing targets among genes preferentially transcribed in haustoria of Puccinia. BMC Genomics 16:579.

Yoshida, K., Schuenemann, V. J., Cano, L. M., Pais, M., Mishra, B., Sharma, R., Lanz, C., Martin, F. N., Kamoun, S., Krause, J. Thines, M., Weigel, D., and Burbano, H. A. 2013. The rise and fall of the Phytophthora infestans lineage that triggered the Irish potato famine. eLife 2:e00731.

Yuan, B., Zhai, C., Wang, W., Zeng, X., Xu, X., Hu, H., Lin, F., Wang, L., and Pan, Q. 2011. The Pik-p resistance to Magnaporthe oryzae in rice is mediated by a pair of closely linked CC-NBS-LRR genes. Theor. Appl. Genet. 122:1017-1028.

Zhang, J., Yin, Z., and White, F. 2015. TAL effectors and the executor $R$ genes. Front. Plant Sci. 6:641.

Zhang, T., Zhao, Y. L., Zhao, J. H., Wang, S., Jin, Y., Chen, Z. Q., Fang, Y. Y., Hua, C. L., Ding, S. W., and Guo, H. S. 2016. Cotton plants export microRNAs to inhibit virulence gene expression in a fungal pathogen. Nat. Plants 2:16153.

Zhou, Y. L., Xu, J. L., Zhou, S. C., Yu, J., Xie, X. W., Xu, M. R., Sun, Y., Zhu, L.-H., Fu, B.-Y., Gao, Y.-M., and Li, Z.-K. 2009. Pyramiding Xa23 and Rxol for resistance to two bacterial diseases into an elite Indica rice variety using molecular approaches. Mol. Breed. 23:279-287.

Zhu, S., Jeong, R. D., Lim, G. H., Yu, K., Wang, C., Chandra-Shekara, A. C., Navarre, D., Klessig, D. F., Kachroo, A., and Kachroo, P. 2013. Doublestranded RNA-binding protein 4 is required for resistance signaling against viral and bacterial pathogens. Cell Rep. 4:1168-1184.

Zhu, S., Jeong, R. D., Venugopal, S. C., Lapchyk, L., Navarre, D., Kachroo, A., and Kachroo, P. 2011. SAG101 forms a ternary complex with EDS1 and PAD4 and is required for resistance signaling against Turnip crinkle virus. PLoS Pathog. 7:e1002318.

Zipfel, C. 2009. Early molecular events in PAMP-triggered immunity. Curr. Opin. Plant Biol. 12:414-420.

Zipfel, C., and Rathjen, J. P. 2008. Plant Immunity: AvrPto targets the frontline. Curr. Biol. 18:R218-R220. 